\title{
The Use of Quantum Learning Model with Islamic Character Values to Improve Fifth Graders' Academic Achievement
}

\author{
Muhamad Afandi $^{1 *}$, Sri Wahyuningsih ${ }^{2}$ \\ 1,Universitas Islam Sulatan Agung, Semarang, Indonesia \\ ${ }^{2}$ Institut Agama Islam Negeri Kudus, Kudus, Indonesia \\ *mafandi@unissula.ac.id
}

\begin{abstract}
This study aims at describing the use of quantum learning model with Islamic character values to improve students' achievement at elementary school. It used a descriptive qualitative method. Data were collected through observation, in-depth interview and documentation. The result indicates that quantum learning model with Islamic character values is beneficial for students during the teaching and learning process. These cover students feel more active in the learning process, students have more attention on teachers' explanations, students have better academic achievement which is shown by the average score among students passing the minimal criteria standard and learning processes and students are able to internalize the Islamic values during teaching and learning process.
\end{abstract}

Keywords: Academic achievement; quantum learning model; Islamic character values.

\section{INTRODUCTION}

Education is an effort to empower people to become fully human beings so that they can actualize themselves, understand themselves and be able to support themselves. In education process, educators can be a facilitator that supports the process of achieving educational goals (Sudarsana, 2016). Learning is the core of the education process that must be designed by the teacher so that its implementation can deliver the students to achieve the specified learning objectives. Learning is interrelated processes with the aim of obtaining and improving a competency for human beings (Nurdyansyah \& Widodo, 2015).

Teachers are one of the educational staff, responsible for the implementation and success of the learning process. The success of learning depends greatly on the facilities and quality of the teachers (Hasan, 2015). It is in line with Zakaria (2016, p. 3) explaining that teachers are the spearhead in the implementation of educational programs in schools. Therefore, the role of teachers is for the success of efforts to improve and equalize the quality of education in 
schools. In this case, the teacher is required to have academic qualifications, competencies, educator certificates, and the ability to realize national education goals. According to Mulyasa (2015), teachers are educators who become leaders, role models, identification for students, and their environment. Therefore, teachers should have certain personal quality standards that include responsibility, authority, independence and discipline. Discipline is meant that teachers obey various rules and regulations consistently. Due to professional awareness, teachers are tasked with disciplining students in schools, especially in learning. Therefore, in instilling discipline, teachers must start from themselves in various actions and behavior.

Primary school teachers are expected to be able to choose the right learning model, one of them is the quantum learning model is a learning strategy or method that makes students fun and motivates students to learn (Ahsin, 2016). The role of Islamic learning media should be in the same direction and in line with the teachings that have been set in the Islamic religion. This is important that students can distinguish, measure, and weigh the value of information or knowledge that comes from instructional media that are prepared without Islamic values so that they are not misled.

Based on the result of observation and interview with teachers, the students' learning responsibilities are considerably low. This is proved by the students' behavior that does not reflect responsibility. This behavior is shown by the number of fifth grade students who violate the rules set by the school such as students were not wearing uniforms completely. For example they were not wearing socks in accordance with uniforms nor wearing black shoes. Another example that shows a lack of responsibility is when students are learning in the class, most of them have no pay attention to the delivery of material delivered by the teachers. In addition, they are busy talking to classmates when learning takes place. In fact, in the teaching and learning process, teachers also do not use instructional media resulting students being less active and disciplined when following the teaching and learning process so that it affects the student learning outcomes.

Based on this problem, it is clear that the low responsibility of students will have an impact on student's learning outcomes. Low learning outcomes are not only influenced by students' lack of responsibility, but also other factors that influence them such as the use of learning methods that only focus on the teacher and do not add methods or learning models that will make students more active in learning process. Students perceive that their learning is boring. In addition, learning materials of grade $\mathrm{V}$ tend to force students to memorize more. Moreover, the lack of students' learning outcomes is evidenced by the scores of Midterm test of students that has not completed the Minimum Mastery 
Criteria determined by the school, 67. It is known from 44 students, only 9 students who have already completed and 35 students are still incomplete. By examining the data of student learning outcomes, it can be concluded that students' learning outcomes in learning can be considered low.

Considering the lack of student's learning outcomes, it is necessary to have the appropriate learning model and media involving students in the learning process for increasing student responsibility and learning outcomes. Thus, a quantum learning model assisted by Islamic character learning media is needed to achieve the learning objectives.

Quantum learning can be defined as a theory of learning allowing to combine all the neutral structures in the brain in a personal strategy to obtain insightful information (Afacan \& Gürel, 2019, p. 87). The concept of quantum learning has previously developed by Bobbi Deporter in 1980 (Zeybek, 2017, p. 17). Quantum learning model can invite students to be more active, enjoyable and comfortable in learning (Sujatmika \& Hakim, 2018, p. 2). Moreover, it is able to foster students to interact more with others and be more active so that their potential can develop (Huda \& Mardikantoro, Hari Bakti, 2018, p. 333).

Interestingly, this study integrates the quantum learning model with Islamic Character values which are considered crucial for students.
Islamic Character values have basically the same role as moral education to foster students to become a good human being having Islamic moral values which can be interpreted as religious values (Wahyuningsih, 2017, p. 833). It can be achieved by a number of ways. One of them is by building positive psychology with Islamic values in children having a tremendous benefit on their abilities to experience their lives and face problems. (Wahyuningsih, 2018, p. 192). Regarding it, Islamic values cover honesty and justice, truth, intention, patience, equality and unity, helping others, hard work, humble, and others. (Rafiki \& Wahab, 2014, p. 2).

In accordance with it, this article explores the use of quantum learning model with Islamic character learning media to improve the students' achievements.

\section{REVIEW OF RELATED LITERATURES}

\section{a. Quantum Learning}

Quantum learning is a learning model that creates an effective learning environment, by using existing elements in students and their learning environment through interactions that occur in the classroom (Agusnanto, 2013, p. 4). The quantum learning is the interaction between educators and students in the learning process at elementary school which is carried out meaningfully to achieve the main objectives in accordance with the potential of students. In this sense, the supporting learning media is needed. 
Media is one of the components of learning. The use of media should be a part that should get the attention of learners in every learning activity. Many types of media can be selected, developed and utilized in accordance with the conditions of time, cost and desired learning objectives. Each type of media has certain characteristics that we need to understand, so that we can choose the appropriate media (Falahudin, 2014). It is in line with Susilana \& Riyana (2008) advocating that media is a sources of the message. Learning media can be a vehicle for learning messages and information. A well designed learning media will greatly help students in digesting and understanding the subject matter (Muhson, 2010). In relation to the function of learning media, the following things can be emphasized: (1) As a means of helping to create a more effective learning situation. (2) As one component that is interconnected with other components in order to create the expected learning situation. Improving the learning process. Improving the quality of teaching and learning process. (5) Interpreting the abstract things so that it can reduce the occurrence of verbalism conflicts (Nurseto, 2011). Islamic character learning media referred to in this study are learning media with Islamic values that are used by teachers in learning to integrate learning material in achieving learning objectives based on themes.

According to DePorter (2009), teaching with Quantum Learning is known as the TANDUR concept, the translation of the TANDUR concept in relation to learning in elementary schools in this study is as follows: (1) The teacher conveys to always be responsible and active in learning (Tumbuhkan), (2) The teacher explains the attitude material contained in the values of Pancasila and relates them to everyday life (Alami). (3) Students who are appointed ahead, are asked to take one example of the attitude of the values of Pancasila and put it in the appropriate precepts (Namai). (4) The teacher appoints students to come forward to the class trying to play the learning media (Demontrasikan). (5) The teacher confirms and emphasizes things that are not understood by students, students reflect on the learning that has been done (Ulangi). (6) The teacher appreciates each student's answer by giving applause or prizes (Rayakan).

\section{b. Learning Outcomes}

Learning is a relatively permanent that occurs in all behavior of an organism as a result of experience. Learning ability possessed by humans is a very basic provision used to achieve higher cultural development (Toyiba, Fitriyani, 2016). Learning outcomes are the process of changing intellectual abilities (cognitive), interest abilities or emotions (affective) and motor skills (psychomotor). Changes in the ability of students in the learning process, especially in basic education units are expected in accordance with the development stage, namely at the operational stage of the congress of the 
fifth grade students (Afandi, Chamalah, \& Wardani, 2013).

\section{c. Islamic Character Values}

Islamic character values can be defined as a way to cultivate intelligence to students in thinking, and behaving in accordance with the noble values that are their identity, manifested in interactions with God, themselves, and others as a realization of God's servants and caliphs SWT (Sa'diyah, 2018, p. 135). Further, the Qur'an describes a whole cluster of terms to denote the concept of moral or religious goodness, such as, al-khayr (goodness), al-birr (righteousness), al-qisr and al-iqsat (equity), al-adl (justice), al-haqq (truth and right), al-ma'ruf (known and approved), and al-taqwa (piety) (Rahim, 2013, p. 509).

In accordance with it, students are badly needed to be fostered these Islamic character values to develop intelligence of students in thinking and behaving based on the Islamic values.

\section{METHODS}

This type of research used is descriptive qualitative research, a place of research in Prampelan Elementary School, Sayung District, Demak Regency. The research subjects were fifth grade students, amounting to 26 students who were given learning with a quantum model of Islamic character in the Civics Education Subjects. Data collection techniques using test techniques. The instrument used was a question sheet with a Minimum Completion Criteria
Standard of Value 65. Analysis of the data by giving a pretest and posttest then the data obtained was then analyzed to obtain the results of the study.

\section{RESULT AND DISCUSSION The Role of Quantum Learning Model in Improving Students' Learning Outcome}

Based on the result of interview, the teacher reveals that the quantum learning model assisted by Islamic character values gives benefits for improving students' learning outcome. These cover:

\section{a. Students feel more active in the learning process}

By using quantum learning model assisted by Islamic character values, students feel more active since the learning process has been designed through games. In this sense, students are divided into several groups and then students play the game while studying. Then, teachers can explain the materials with Islamic character values. In other words, quantum learning can one of the learning model that can attract students to be more active during teaching and learning process (Dyah KUSUMA, Gunarhadi, \& Riyadi, 2018, p. 10). The students' activeness has been advocated by Istiqomah, the teacher at elementary school, Prampelan:

"Before using quantum learning model in the learning process, students tend to feel passive in class. They are busily chatting and playing with their 
friends. Surprisingly, after using quantum learning model with Islamic character values, students feel more active in learning process. They are motivated by the game including the Islamic values designed by the teacher. For example: in teaching Civic Education, teachers can give the materials of the main points of PANCASILA in which the Islamic character values can be internalized including: having the belief to God, having well humanity, and so on." (Istiqomah, October 2019).

\section{b. Students have more attention on teachers' explanations}

Before using quantum learning model in the learning process, students tend to be busy with their friend such as chatting and playing. Moreover, they have no more attention when the teacher explains the materials. Considering this, the teacher has initiated to use quantum learning model with Islamic character values designed by using games. Interestingly, most students show their enthusiasm during the teaching and learning process. It has been proved by the descriptions of the teacher at Elementary school, Prampelan:

"Quantum learning model with Islamic cultural values have been beneficial for students. It was designed by using interactive games making the students are active and paying more attention on the teachers' instruction and explanations. Students are actively answering the questions from the teachers. In fact, they feel more enthusiastic in learning process" (Istiqomah, October 2019)

\section{c. Students have better academic achievement}

Before using quantum learning model with Islamic character values, the students' learning outcome can be considered low shown by their low score that does not pass the minimal criteria standard. It may be caused by their less motivation in learning process, the monotonous learning method and others. Having been taught using quantum learning model with Islamic character values, students become more enthusiastic and get better score in several subjects. Regarding this, it proves that quantum learning model with Islamic character values can increase the students' learning outcome. This finding is in accordance with Wulanditya (2016, p. 13) asserting that quantum learning can be an alternative to improve students' learning outcome. In other words, it can be said that quantum learning has a positive influence on academic achievements and selfconfidence among students (Zeybek, 2017 , p. 10). It has been proved by the following table of students' score in civic subject. 


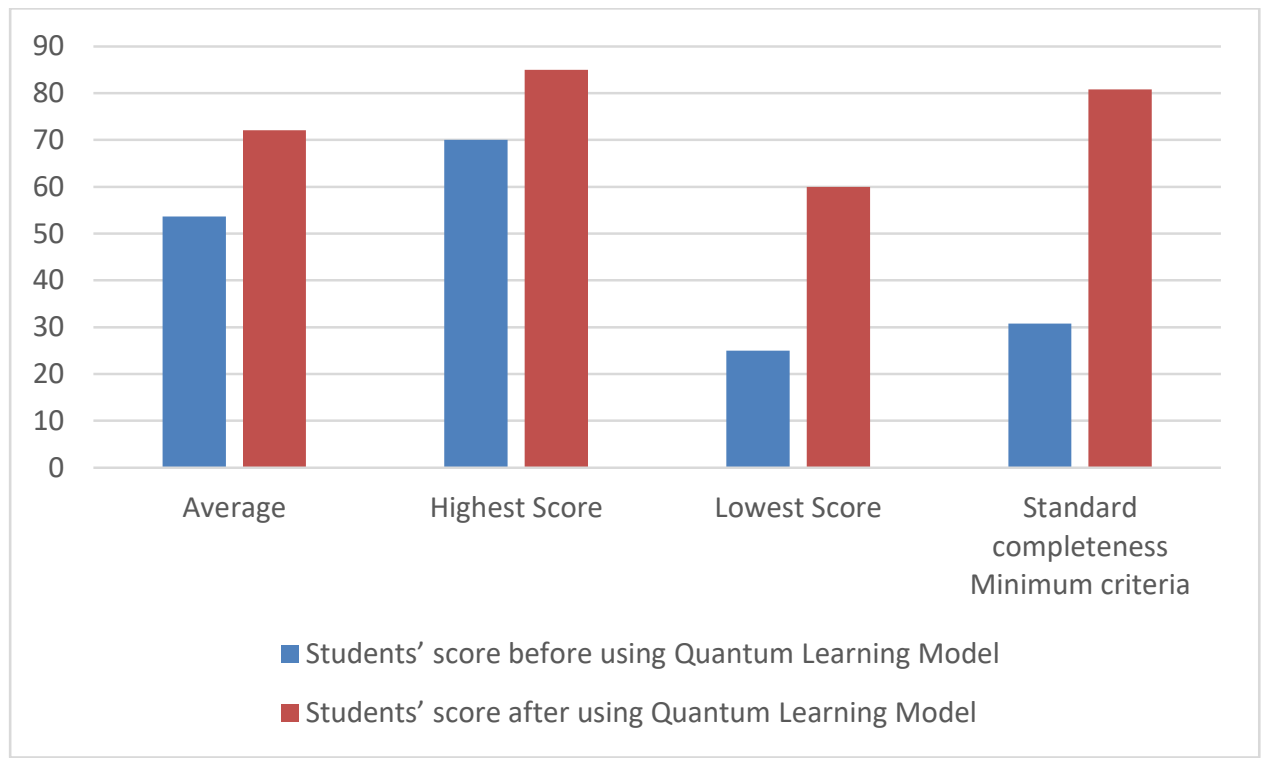

Figure 1. Students Learning Outcomes

Figure 1 highlights that the average score is 53.65 , the highest score is 70 , the lowest score is 25 while the minimum standard completeness criteria is $30.77 \%$. Most students get low scores in citizenship subjects before being taught using a quantum learning model with Islamic character values. In this case, most of them did not pass the minimum criteria standard of 65 , there were 18 students out of 26 students who did not pass the minimum criteria standard or $69.23 \%$. After being taught using quantum learning with Islamic character values, students showed their better scores in the subjects of citizenship namely an Average Score of 53.65, a Highest Score of 85, a Lowest Score of 60 while a Standard completeness Minimum criterion of $80.77 \%$. In addition, it was revealed that only five students did not pass the minimum criteria standard, others could be very successful in citizenship subjects because they had passed the minimum criteria standard. In other words, the success of learning using the citizenship learning model has reached $80.77 \%$.

\section{d. Students are able to internalize the Islamic values during teaching and learning process.}

It has been already known that students in elementary school, Prampelan are Moslem. Therefore, the Islamic character values are badly needed at an early age including at Elementary School. Considering this, the teachers are motivated to use quantum learning model with Islamic character values. By using it, students have more awareness on religious values such as believing to God, respecting human beings, having justice to human beings 
and so on. As a result, students will have more social skills through the quantum learning model assisted by Islamic character values. It is in line with Afacan \& Gürel (2019, p. 87) revealing that quantum learning has promoted communication skills and interaction with others

\section{CONCLUSION}

The quantum learning model with Islamic character values is one of the learning models that need to be applied in teaching students in Elementary Schools in Citizenship Education Subjects. The results showed that there were students who passed the minimum criteria standard reaching $80.77 \%$, as many as 21 people out of 26 fifth grade students, with a grade average grade of 72.12. The application of quantum learning models with Islamic character values has a better impact on student achievement and self-confidence. In addition, there are several benefits of using a quantum learning model with Islamic character values including students feeling more active in the learning process, students have more attention on the teacher's explanation, students have maximum results in the teaching and learning process and students can internalize Islamic values during the process learn how to teach..

\section{REFERENCES}

Afacan, Ö., \& Gürel, İ. (2019). The Effect of Quantum Learning Model on Science Teacher Candidates' Self-
Efficacy and Communication Skills. Journal of Education and Training Studies, 74), 86-95. https://doi.org/10.11114/jets.v7i4.4 026

Afandi, M., Chamalah, E., \& Wardani, O. P. (2013). Model dan Metode Pembelajaran di Sekolah. In Diakses dari http://www. Fcyber. unissula. ac. id\% 2Fjournal\% 2Fdosen\% 2Fpublikasi\% 2F2 (Vol. 11313015). Bandung: Alfabeta.

Agusnanto. (2013). Penerapan model pembelajaran. Jurnal PGSD Universitas Surabaya, 01 Nomor 0, 0-216.

Ahsin, M. N. (2016). Peningkatan Keterampilan Menulis Karangan Narasi Dengan Menggunakan Media Audiovisual Dan Metode Quantum Learning. Refleksi Edukatika, 6(2), 158-171.

https://doi.org/10.24176/re.v6i2.607

DePorter, B. et. al. (2009). Quantum Teaching (Mempraktikkan Quantum Learning di ruang-ruang kelas). Penerjemah: Ary Nilandari. Bandung: Penerbit Kaifa.

Dyah KUSUMA, E., Gunarhadi, G., \& Riyadi, R. (2018). The Development of Problem-Based Quantum Learning Model in Elementary Schoolin. International Journal of Educational Research Review, 3(3), 9-16. https://doi.org/10.24331/ijere.41226 7

Falahudin, I. (2014). Pemanfaatan Media dalam Pembelajaran. Lingkar Widyawiswara, 1(Desember), 104117. 
Hasan, H. (2015). Kendala yang dihadapi Guru dalam Proses Belajar Mengajar Matematika di SD Negeri Gani Kabupaten Aceh Besar. Jurnal Pesona Dasar, 1(4), 40-51.

Huda, W., \& Mardikantoro, Hari Bakti, H. (2018). Quantum Learning Model Influence using Series of Drawings Towards The Fifth Grade Students ' Narrative Writing Skill. Journal of Primary Education, 73), 332-341.

Muhson, A. (2010). Pengembangan Media Pembelajaran Berbasis Teknologi Informasi. Pendidikan Akuntansi Indonesia, VIII(2), 1-10.

Mulyasa, E. (2015). Menjadi Guru Profesional. Bandung: Rosdakarya.

Nurdyansyah, \& Widodo, A. (2015). Inovasi Teknologi Pembelajaran. Sidoarjo: Nizamia Learning Center.

Nurseto, T. (2011). Membuat Media Pembelajaran yang Menarik. Ekonomi \& Pendidikan, 8, 19-35. https://doi.org/media pembelajaran

Rafiki, A., \& Wahab, K. A. (2014). Islamic Values and Principles in the Organization: A Review of Literature Islamic Values and Principles in the Organization: A Review of Literature. Asian Social Science, 10(9), 1-8. https://doi.org/10.5539/ass.v10n9p1

Rahim, A. B. A. (2013). Understanding Islamic Ethics and Its Significance on the Character Building. International Journal of Social Science and Humanity, 3(6), 508-513. https://doi.org/10.7763/ijssh.2013.v 3.293

Sa'diyah, H. (2018). Internalization of
Islamic Character Education to Students in Elementary School (SD) Plus Nurul Hikmah Pamekasan Madura. International Journal on Islamic Educational Research (SKIJER), 2(1), 134-145.

Sudarsana, I. K. (2016). Pemikiran Tokoh Pendidikan Dalam Buku Lifelong Learning: Policies, Practices, And Programs (Perspektif Peningkatan Mutu Pendidikan di Indonesia). Jurnal Penjaminan Mutu, 2(2), 44. https://doi.org/10.25078/jpm.v2i2.7 1

Sujatmika, S., \& Hakim, L. L. (2018). Effect of quantum learning model in improving creativity and memory. Journal of Physics: Conference Series, 1006, 1-7. https://doi.org/10.1088/17426596/1006/1/012036

Susilana, R., \& Riyana, C. (2008). Media pembelajaran: hakikat, pengembangan, pemanfaatan, dan penilaian. CV. Wacana Prima, 2008. In Wacana Prima. Bandung: Wacana Prima.

Toyiba, Fitriyani, N. (2016). Pengaruh Strategi pembelajaran Aktif Terhadap hasil belajar pada Madrasah Ibtidaiyah. Pendidikan Guru Madrasah Ibtidaiyah, 1(2), 929-930.

Wahyuningsih, S. (2017). Empowering the Character Education for Indonesian People in Facing ASEAN Economic Community (AEC). The Ist Education and Language International Conference Proceedings Center for International 


\section{Language Development of Unissula,} 832-841.

Wahyuningsih, S. (2018). Promoting Children 's Spiritual Intelligence and Personality Development. Jurnal Penelitian, 15(2), 189-201.

Wulanditya, P. (2016). Quantum Learning: Experiment To Increase Learning Outcomes. Journal of Accounting and Business Education, 1(4).

https://doi.org/10.26675/jabe.v1i4.6 039

Zakaria, T. R. (2016). Pembaharuan Mutu Guru. In Buletin BSNP. Jakarta. Zeybek, G. (2017). An Investigation on Quantum Learning Model. International Journal of Modern Education Studies, 1(1), 16-27. 